\title{
Are We Ready For Covid - 19 Vaccines? - A General Side Effects Overview
}

\section{Dr. Lipika Das ${ }^{1 *}$, Dr. Meghana A², Dr. Prolay Paul ${ }^{3}$, Dr. Sayantan Ghosh ${ }^{4}$}

\begin{abstract}
${ }^{1}$ Pharm D Intern Dept. of Pharmacy Practice Sri Adichunchanagiri College of Pharmacy B.G. Nagara, 571448 Orcid id: 0000-0003-1120-2989
\end{abstract}

${ }^{2}$ Pharm D Intern Dept. of Pharmacy Practice Sri Adichunchanagiri College of Pharmacy B.G. Nagara, 571448 Orcid id: 0000-0002-6467-4878

${ }^{3}$ Pharm D Intern Dept. of Pharmacy Practice Sri Adichunchanagiri College of Pharmacy B.G. Nagara, 571448 Orcid id: 0000-0001-7042-3314

${ }^{4}$ Pharm D Intern Dept. of Pharmacy Practice Sri Adichunchanagiri College of Pharmacy B.G. Nagara, 571448 Orcid id: 0000-0003-3729-4834

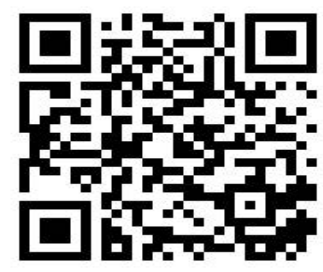

\begin{abstract}
:
A vaccine is considered to be one of the best options in public health safety, specifically when there is no effective vaccine available against that infectious disease. ${ }^{6}$ Classic vaccine development often takes years, but developing a vaccine for the prevention of Covid- 19 has turned out to be a race between viruses and humans, and along with the identification of other similar strains has made it more difficult. COVID- 19 has serious and life-threatening complications and no one knows how COVID- 19 is affecting. ${ }^{13}$ Firstly vaccines are given to health care workers in public and private. The vaccine is first given to one crore healthcare workers around India working in both government and private hospitals according to the recommendation by NEGVAC. It is mandatory to monitor the patient for the next 15 minutes after taking the Covid 19 Vaccine shot. Most of the side effects occur within the next 3 days after vaccination. If someone has a history of allergic reactions which is not related to vaccines or injectable medications, they can still take Covid 19 Vaccine. If someone getting an immediate allergic reaction after getting the first dose of Covid 19 Vaccine, then he/she should not take the second dose of the vaccine. Even though the vaccination strategy throughout the globe is in peak, the people are asked to follow the similar guidelines to prevent the transmission of corona virus. Therefore throughout the world, several ministries of health and family welfare have asked people to maintain social distancing, wearing facemasks in public, using hand sanitizers, washing hands, avoid crowded places and maintain personal hygiene.
\end{abstract}

Keywords: Vaccines, Covid 19, Side Effect, Clinical Trials, Covaxin, Covishield

\section{Introduction:}

A novel beta- coronavirus is presumed to have emerged in Wuhan, China in December 2019, by the World Health Organization. The virus speedily feasted globally within 3 months and as of March 11, 2020, was considered a pandemic by the World Health Organization. ${ }^{1}$ The infection spread through human to the human transmission after over passing the species barriers. The beta- coronavirus has caused several zoonotic outbreaks like SARS CoV from 2002-2003, MERS- CoV in 2012, and SARS- CoV- 2 since 2019. ${ }^{2}$ On November 3, 2020, more than 46 million confirmed cases have been reported along with more than 1 million died globally. The infected patients experience a broad 
range of symptoms like cough, fatigue, fever, and shortness of breath. ${ }^{3,4}$ Patients with severe pneumonia have other complications like changes in the heart and liver function, acute respiratory distress syndrome, or other consequences of the disease, which could further cause multiple organ failures and finally death. ${ }^{5}$ Vaccines are responsible for saving millions of patients every year. The body's defenses (the immune system) are prepared and trained by the vaccines. These natural defenses identify and fight off the viruses and other germs they target. The body will instantly destroy them as soon as it gets exposed to the disease-causing viruses and bacteria, thus preventing illness. ${ }^{6}$

A vaccine is considered to be one of the best options in public health safety, specifically when there is no effective vaccine available against that infectious disease. ${ }^{6}$ Classic vaccine development often takes years, but developing a vaccine for the prevention of Covid- 19 has turned out to be a race between viruses and humans, and along with the identification of other similar strains has made it more difficult. Numerous platforms are trying their hands in development, among which the DNA and RNA based platforms are at greatest potential, followed by recombinant-subunit vaccines. ${ }^{7}$ Several countries have joined this battle of vaccine development and have speed up the process of clinical trials and is trying to develop an effective and harmless vaccine against Covid- $19 .{ }^{8}$ The various approaches for the development of vaccine includes both next-generation techniques and traditional methods. In the early days, usually vaccines consist of less virulent (but still immunogenic), inactive whole virus, or subunits of viruses. Live vaccines are not included in the prevention of Covid- 19 for safety purposes, whereas inactive whole virus vaccines have been taken into account. ${ }^{9}$

\section{Methodology:}

This review has analyzed the data collected from various articles, guidelines, healthcare sector organization's strategies to promote and improve the pre and post vaccination strategies and to improve the healthcare system overall.

\section{Vaccination Strategies in Different Countries:}

\section{Europe}

- The main objective of vaccination strategy depends on saving the life, reducing mortality, and reducing pressure on the healthcare system.
- The prioritization mainly depends on the features and characteristics of the vaccine, particularly its effectiveness against infection and further ahead transmission.

- If the vaccination dose does not protect against the transmission, the most efficient and effective method is to hierarchize the vaccination of the groups which are at the highest risk of severe disease and death.

- Substantially reducing the mortality and pressure on the healthcare system might be achieved by direct protection of groups that are at high risk, even if the transmission of the virus is going on within the population.

- Vaccination to the health workers is very much beneficial as it improves the healthcare system's resilience. The advantage would be more if a vaccine was more effective against infection and thus transmission, indirect protection to patients and other high-risk individuals.

- Though vaccinating adults with the age group of 18- 59 years is not the most efficient or effective strategy when the supply of vaccine is limited, specific groups must be considered or the groups which are at the high risk of exposure.

- Regarding the COVID- 19 vaccine development of the characteristics uptake and supply, to escape variants from the future appearance, interventions of nonpharmaceuticals which should be applied and continued, as it is recommended by the public health authorities in the initial months of following the introduction of the COVID- 19 vaccination.

- Vaccination ideas or strategies should be adapted over time to unfold events that are taken into the account in emerging evidence. $^{10}$

\section{Corresponding Author:}

Dr. Lipika Das

Pharm D Intern Dept. of Pharmacy Practice Sri Adichunchanagiri College of Pharmacy B.G. Nagara, 571448 Orcid id: 0000-0003-1120-2989 Email:drlipikadas24@hotmail.com 
The Government is negotiating strongly to build a portfolio that is diversified to vaccines for European citizens at fair and less prices. Agreements have been with Sanofi- GSK with 300 million doses, Johson and johnson with 400 million doses, BioNTech-Pfizer with 600 million doses, Astrazeneca with 400 million doses, Moderna with 160 million doses, and CureVac with 405 million doses. The commission has been concluded with exploratory talks with a pharmaceutical company like Novavax with the view by purchasing up to 200 million doses and Valneva with a purchase of up to 60 million doses. The candidate who took vaccines turned out to be safe and effective. Member states can donate the part of their doses to middle- and lower-income countries. By March 2021, 80\% of the health and social care professionals and $80 \%$ of people over the age of 80 in every member state should be vaccinated.

By March 2021, 70\% of the entire adult population in member states should have to be vaccinated. The member states, commission and EMA will assess and work with the companies to use the EU's potential for increasing the vaccine manufacturing capacity to its fullest. ${ }^{11}$

\section{India}

The main objectives of the COVID- 19 vaccine strategy in India is

- To make sure that all the eligible groups receive the vaccine with self-confidence.

- All people will get the exact and correct information and are not influenced by myths, misinformation, and misconceptions.

- Indecision of the public is addressed on Corona (COVID-19) vaccination process.

- Provide consistent, correct, and timely information on new COVID- 19 vaccines, their availability, timeliness, and safety and processes.

- Mainly understanding and generating awareness of the phased method of prioritizing the target groups.

- Address the low-risk perception of infection amongst people and built the environment to maintain and adopt Corona proper behaviors to reduce the risk of infection. ${ }^{12}$
Actions are taken at the Country level

- Development of Training Communication Package for IEC officers on planning, communicating, and implementing on COVID- 19 vaccine.

- Improving the building capacity module on the social mobilization and inner personal communication for ANMs, ASHAs, and AWW and social mobilizers like SHGs, MAS, PRIs, NSS, NYKS, CSO, religious leaders, and CBOs, etc. which can be adapted at state levels.

- Conducting National Training for Trainers (ToT) on this pandemic of COVID- 19 vaccination process which includes social mobilization, communication, and implementation and planning for IEC officers.

- Conducting the capacity building of national helpline number at 1075 and state helpline at 104 with the call center staff.

- Conducting the conference in social media for social media managers like representatives of IEC Bureau, state information Bureau, etc.

- Training the trainers who are masters to conduct state and district level sessions for training the FLWs and other communication.

- Identify the national-level partners, Interfaith Humanitarian Alliance, including SBCC Alliance, Red Cross to adapt the package to reach the networks. ${ }^{12}$

Key actions at the State level

- At the State level, utilizing the State Steering Committee for coordination of inter-department to support the awareness generation.

- Influencing the state task force to supervise and develop state communication plan which is annexed for Corona (COVID- 19) vaccination rollout, which includes the monitoring the mechanisms.

- Preparing and disseminating the written appeal from the Chief Minister to all the elected representatives and Magistrates of the District.

- Adapting and developing the communication package plan and material in the local languages.

- Organizing the advocacy events with the religious leaders and the faith-based 
institutions which include the written appeal, video or audio bytes, mikingamplified through the electronic, print media, and social media.

- Involving all the local celebrities including the digital media champions. ${ }^{12}$

COVID- 19 has serious and life-threatening complications and no one knows how COVID- 19 is affecting. ${ }^{13}$ Firstly vaccines are given to health care workers in public and private. The vaccine is first given to one crore healthcare workers around India working in both government and private hospitals according to the recommendation by NEGVAC (National Expert Group on Vaccine Administration for COVID- 19). Next after healthcare workers, frontline and municipal workers, and areas with high-risk COVID-19 infection. ${ }^{14}$ Delivering the two doses each to the 30 crore people by September 2021 is the main goal of the Indian government. ${ }^{15}$

\section{US}

Presently, 3 million doses of corona vaccine had been shipped throughout the United States with an equal number and the second dose is held back to maintain the sufficient supply. In the US the priority is given mainly for the first dose to more people as possible, relatively than stressing the second dose. ${ }^{16}$
In the first phase all healthcare workers and first responders, in the second phase people who are the underlying condition that put them to the high risk of severe COVID- 19 disease, in the third phase to all essential service workers at high risk of exposure, school staff, teachers, older adults who have not been treated for their symptoms, people who are homeless, and in prisons. In phase 4 young adults, children, and essential workers, and in the fifth phase, all the residents will get vaccinated. ${ }^{17}$

\section{China}

In China, there are certain categories to receive the vaccine which include health care sector workers, workers who help in delivery, public servants, people whose jobs require overseas travel, and utility employees. Recently it got updated that 73,500 people received the first vaccine dose in the first two days of 2021. In-state media of China reported that more than 200 vaccinated sites were placed in the city of Beijing alone. ${ }^{18}$

The new information has been released that China's center for Disease Control collected the blood samples from $4.43 \%$ of Wuhan's population contained corona antibodies which indicates that the city of infection rate is far higher than originally acknowledged. ${ }^{18}$

\section{Phases of different vaccines}

\begin{tabular}{|c|c|c|c|c|}
\hline $\begin{array}{l}\text { Sl. } \\
\text { no }\end{array}$ & Type & Phases & Mechanism of action & Sponsor \\
\hline 1. & $\begin{array}{c}\text { JNJ- } 78436735 \\
\text { (Formerly Ad26. } \\
\text { COV2.S) }\end{array}$ & Phase 3 & $\begin{array}{l}\text { It's a non-replicating } \\
\text { viral vector }\end{array}$ & Johnson \& Johnson \\
\hline 2. & NVX-CoV2373 & Phase 3 & $\begin{array}{l}\text { It is a nanoparticle } \\
\text { vaccine }\end{array}$ & $\underline{\text { Novavax }}$ \\
\hline 3. & $\begin{array}{c}\text { Convidicea (Ad5- } \\
\text { nCoV) }\end{array}$ & Phase 3 & $\begin{array}{l}\text { It is a recombinant } \\
\text { vaccine (adenovirus } \\
\text { type } 5 \text { vector) }\end{array}$ & $\underline{\text { CanSino Biologics }}$ \\
\hline 4. & $\begin{array}{c}\text { Bacillus } \\
\text { Calmette- Guerin } \\
\text { (BCG) vaccine }\end{array}$ & $\begin{array}{l}\text { Phase } \\
2 / 3\end{array}$ & $\begin{array}{l}\text { It is a live attenuated } \\
\text { vaccine }\end{array}$ & $\begin{array}{l}\frac{\text { University of Melbourne and }}{\text { Murdoch Children's Research }} \\
\underline{\text { Institute; Radboud University }} \\
\frac{\text { Medical Center; Faustman Lab }}{\text { at Massachusetts General }} \\
\text { Hospital }\end{array}$ \\
\hline 5. & INO- 4800 & $\begin{array}{l}\text { Phase } \\
2 / 3\end{array}$ & $\begin{array}{c}\text { It's a DNA vaccine } \\
\text { (Plasmid) }\end{array}$ & Inovio Pharmaceuticals \\
\hline 6. & VIR- 7831 & $\begin{array}{c}\text { Phase } \\
2 / 3 \\
\end{array}$ & $\begin{array}{l}\text { It's a plant-based } \\
\text { adjuvant vaccine }\end{array}$ & Medicago; $\underline{\text { GSK }}$; Dynavax \\
\hline 7. & $\begin{array}{c}\text { No name } \\
\text { announced }\end{array}$ & $\begin{array}{l}\text { Phase } \\
2 / 3\end{array}$ & $\begin{array}{l}\text { It's an adenovirus- } \\
\text { based vaccine }\end{array}$ & ImmunityBio; NantKwest \\
\hline 8. & $\mathrm{CVnCoV}$ & $\begin{array}{c}\text { Phase } \\
2 \mathrm{~b} / 3\end{array}$ & $\begin{array}{l}\text { It's an mRNA-based } \\
\text { vaccine }\end{array}$ & $\underline{\text { CureVac }}$ \\
\hline
\end{tabular}




\begin{tabular}{|c|c|c|c|c|}
\hline 9. & ZF 2001 & Phase 2 & $\begin{array}{l}\text { It's a Recombinant } \\
\text { vaccine }\end{array}$ & $\begin{array}{c}\text { Anhui Zhifei Longcom } \\
\text { Biopharmaceutical, Institute of } \\
\text { Microbiology of the Chinese } \\
\text { Academy of Sciences }\end{array}$ \\
\hline 10. & ZyCoV-D & Phase 2 & $\begin{array}{c}\text { It's a DNA vaccine } \\
\text { (Plasmid) }\end{array}$ & $\underline{\text { Zydus Cadila }}$ \\
\hline 11. & BNT 162 & $\begin{array}{l}\text { Phase } \\
1 / 2 / 3\end{array}$ & mRNA based vaccine & Pfizer, BioNTech \\
\hline 12. & EuCorVac-19 & Phase $1 / 2$ & It's a nanoparticle & EuBiologics \\
\hline 13. & $\begin{array}{l}\text { Mambacisa } \\
\text { (CIGB 669) }\end{array}$ & Phase $1 / 2$ & $\begin{array}{l}\text { It's a protein subunit } \\
\text { vaccine }\end{array}$ & Finlay Institute of Vaccines \\
\hline 14. & IIBR- 100 & Phase $1 / 2$ & $\begin{array}{c}\text { It's a recombinant } \\
\text { vesicular stomatitis } \\
\text { virus (rVSV) vaccine }\end{array}$ & $\begin{array}{c}\text { Israel Institute for Biological } \\
\text { Research }\end{array}$ \\
\hline 15. & $\begin{array}{c}\text { No name } \\
\text { announced }\end{array}$ & Phase $1 / 2$ & $\begin{array}{l}\text { It's an SF } 9 \text { cell } \\
\text { vaccine candidate }\end{array}$ & $\begin{array}{c}\text { West China Hospital, Sichuan } \\
\text { University }\end{array}$ \\
\hline 16. & Soberna 1 and 2 & Phase $1 / 2$ & $\begin{array}{l}\text { It's a monovalent or } \\
\text { conjugate vaccine }\end{array}$ & Finlay Institute of Vaccines \\
\hline 17. & VLA2001 & Phase $1 / 2$ & $\begin{array}{l}\text { It's an inactivated } \\
\text { vaccine }\end{array}$ & $\begin{array}{l}\text { Valneva; National Institute for } \\
\text { Health Research (NIHR) }\end{array}$ \\
\hline 18. & $\begin{array}{l}\text { No name } \\
\text { announced }\end{array}$ & Phase $1 / 2$ & $\begin{array}{l}\text { It's an adjuvanted } \\
\text { protein subunit } \\
\text { vaccine }\end{array}$ & CEPI \\
\hline 19. & $\begin{array}{l}\text { AG0301- } \\
\text { COVID- } 19\end{array}$ & Phase $1 / 2$ & It's a DNA vaccine & AnGes, Inc. \\
\hline 20. & GX-19N & Phase $1 / 2$ & It's a DNA vaccine & Genexine \\
\hline 21. & $\begin{array}{l}\text { ARCT- } 021 \\
\text { (LUNAR- COV } \\
19) \\
\end{array}$ & Phase $1 / 2$ & $\begin{array}{l}\text { It's a self-replicating } \\
\text { RNA vaccine }\end{array}$ & $\begin{array}{c}\underline{\text { Arcturus }} \\
\text { Therapeutics and Duke-NUS } \\
\text { Medical School }\end{array}$ \\
\hline 22. & $\begin{array}{l}\text { No name } \\
\text { announced }\end{array}$ & Phase $1 / 2$ & $\begin{array}{l}\text { It's a protein subunit } \\
\text { vaccine }\end{array}$ & $\underline{\text { Sanofi; } \text { GlaxoSmithKline }}$ \\
\hline 23. & $\begin{array}{l}\text { No name } \\
\text { announced }\end{array}$ & Phase $1 / 2$ & $\begin{array}{l}\text { It's an inactivated } \\
\text { vaccine }\end{array}$ & $\begin{array}{l}\text { Chinese Academy of Medical } \\
\text { Sciences, Institute of Medical } \\
\text { Biology }\end{array}$ \\
\hline 24. & $\begin{array}{l}\text { HDT- 301 } \\
(\text { HGC019) }\end{array}$ & Phase $1 / 2$ & It's an RNA vaccine & $\begin{array}{c}\underline{\text { University of }} \\
\frac{\text { Washington; National Institutes }}{\text { of Health Rocky Mountain }} \\
\frac{\text { Laboratories; HDT Bio }}{\text { Corp; Gennova }} \\
\text { Biopharmaceuticals }\end{array}$ \\
\hline 25. & AdCLD- CoV19 & $\begin{array}{c}\text { Phase } \\
1 / 2 \mathrm{a}\end{array}$ & $\begin{array}{l}\text { It's an adenovirus- } \\
\text { based vaccine }\end{array}$ & Cellid; LG Chem \\
\hline 26. & AV-COVID- 19 & $\begin{array}{l}\text { Phase } \\
1 \mathrm{~b} / 2\end{array}$ & $\begin{array}{l}\text { It's a dendritic cell } \\
\text { vaccine }\end{array}$ & Aivita Biomedical, Inc. \\
\hline 27. & $\begin{array}{l}\text { PTX- COVID19- } \\
\text { B } \\
\end{array}$ & Phase 1 & $\begin{array}{l}\text { It's an mRNA- based } \\
\text { vaccine }\end{array}$ & $\begin{array}{l}\text { Providence Therapeutics; } \\
\text { Canadian government }\end{array}$ \\
\hline 28. & $\begin{array}{c}\text { Abdala (CIGB } \\
66) \\
\end{array}$ & Phase 1 & $\begin{array}{l}\text { It's a protein subunit } \\
\text { vaccine }\end{array}$ & Finlay Institute of Vaccines \\
\hline 29. & COVI- VAC & Phase 1 & $\begin{array}{l}\text { It's an intranasal } \\
\text { vaccine }\end{array}$ & $\begin{array}{l}\text { Codagenix; Serum Institute of } \\
\text { India }\end{array}$ \\
\hline 30. & CORVax 12 & Phase 1 & $\begin{array}{l}\text { It's a DNA vaccine } \\
\text { (plasmid) }\end{array}$ & $\begin{array}{l}\text { OncoSec; Providence Cancer } \\
\text { Institute }\end{array}$ \\
\hline 31. & MVA- SARS-2-S & Phase 1 & $\begin{array}{c}\text { It's a modified } \\
\text { vaccinia virus Ankara } \\
\text { (MVA) vector } \\
\text { vaccine }\end{array}$ & $\begin{array}{l}\text { Universitätsklinikum Hamburg- } \\
\text { Eppendorf; German Center for } \\
\text { Infection Research; Philipps } \\
\text { University Marburg Medical } \\
\text { Center; Ludwig-Maximilians - } \\
\text { University of Munich }\end{array}$ \\
\hline
\end{tabular}




\begin{tabular}{|c|c|c|c|c|}
\hline 32. & COHO4S1 & Phase 1 & $\begin{array}{c}\text { It's a modified } \\
\text { vaccinia virus Ankara } \\
\text { (MVA) vector } \\
\text { vaccine } \\
\end{array}$ & $\begin{array}{l}\text { City of Hope Medical Center; } \\
\text { National Cancer Institute }\end{array}$ \\
\hline 33. & $\mathrm{pVAC}$ & Phase 1 & $\begin{array}{l}\text { It's a multi-peptide } \\
\text { vaccine }\end{array}$ & University Hospital Tuebingen \\
\hline 34. & AdimrSC- $2 f$ & Phase 1 & $\begin{array}{l}\text { It's a protein subunit } \\
\text { vaccine }\end{array}$ & $\underline{\text { Adimmune }}$ \\
\hline 35. & bac-TRL- Spike & Phase 1 & $\begin{array}{c}\text { It's a monovalent oral } \\
\text { vaccine } \\
\text { (bifidobacteria) }\end{array}$ & $\underline{\text { Symvivo }}$ \\
\hline 36. & COVAX- 19 & Phase 1 & $\begin{array}{l}\text { It's a monovalent } \\
\text { recombinant protein } \\
\text { vaccine }\end{array}$ & Vaxine Pty Ltd. \\
\hline 37. & $\begin{array}{c}\text { DelNS1- 2019- } \\
\text { nCoV- RBD- } \\
\text { OPT } 1\end{array}$ & Phase 1 & $\begin{array}{l}\text { It's a replicating viral } \\
\text { vector }\end{array}$ & $\begin{array}{l}\text { Xiamen University, Beijing } \\
\text { Wantai Biological Pharmacy }\end{array}$ \\
\hline 38. & GRAd- COV2 & Phase 1 & $\begin{array}{l}\text { It's an adenovirus- } \\
\text { based vaccine }\end{array}$ & $\underline{\text { ReiThera }} ; \frac{\text { Leukocare; Univercel }}{\underline{1 \mathrm{~s}}}$ \\
\hline 39. & UQ- CSL V451 & Phase 1 & $\begin{array}{l}\text { It's a protein subunit } \\
\text { vaccine }\end{array}$ & $\underline{\text { CSL; }} \frac{\text { The University of }}{\text { Queensland }}$ \\
\hline 40. & SCB- 2019 & Phase 1 & $\begin{array}{l}\text { It's a protein subunit } \\
\text { vaccine }\end{array}$ & $\begin{array}{l}\frac{\text { GlaxoSmithKline, }}{\underline{\mathrm{r}}}, \underline{\text { Sanofi, }}, \underline{\text { Clove }} \\
\frac{\text { Biopharmaceuticals }}{\text { nd Xiamen Innovax; CEPI }}\end{array}$ \\
\hline 41. & UB- 612 & Phase 1 & $\begin{array}{c}\text { It's a multitype } \\
\text { peptide-based vaccine }\end{array}$ & COVAXX \\
\hline 42. & VXA- COV2- 1 & Phase 1 & $\begin{array}{l}\text { It's a recombinant } \\
\text { vaccine (adenovirus } \\
\text { type } 5 \text { vector). }{ }^{19}\end{array}$ & $\underline{\text { Vaxart }}$ \\
\hline
\end{tabular}

Table- List of Authorized Vaccines around the globe-

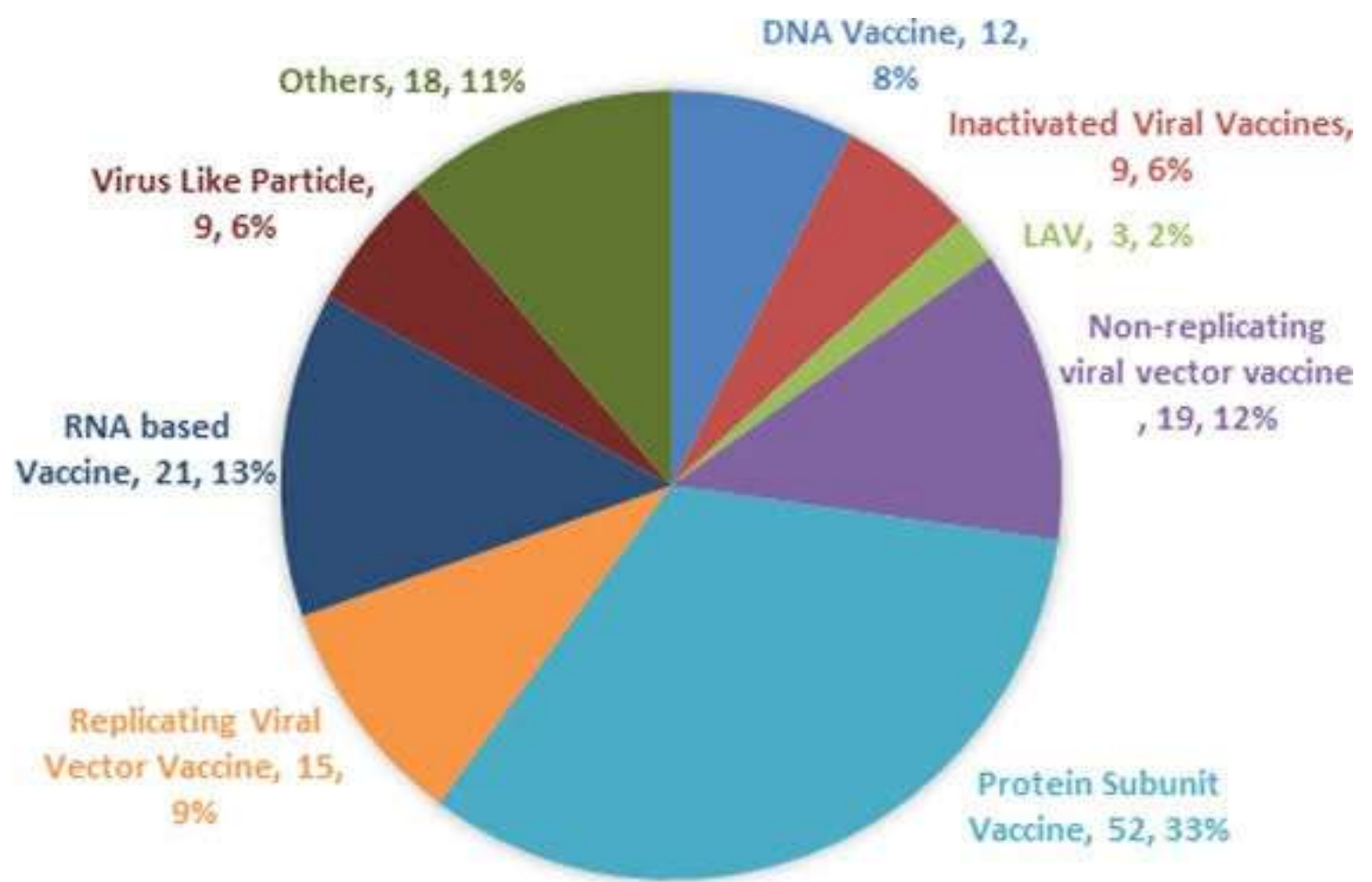

Figure- Pie Chart representation of COVID 19 Vaccine used around the globe 


\section{Advantages and Limitations of Covid-19 Vaccines Currently}

\begin{tabular}{|c|c|c|c|c|}
\hline Sl.no & Vaccine & Nation & Advantages & Limitations \\
\hline 1. & $\begin{array}{l}\text { Comirnaty } \\
\text { (BNT } \\
162 \mathrm{~b} 2 \text { ) }\end{array}$ & $\begin{array}{l}\text { Multinational(United Kingdom, } \\
\text { Bahrain, Canada, Mexico, US, } \\
\text { Singapore, Costa Rica, Ecuador, } \\
\text { Jordan, Panama, Chile, Oman, } \\
\text { Saudi Arabia, Argentina, } \\
\text { Switzerland, Kuwait, EU, } \\
\text { Philippines, Pakistan, } \\
\text { Colombia, Iraq, Israel, Qatar, } \\
\text { Singapore, United Arab } \\
\text { Emirates, Faroe Islands, } \\
\text { Greenland, Iceland, Malaysia, } \\
\text { Norway, Serbia, Hong Kong, } \\
\text { Albania, Australia) }\end{array}$ & $\begin{array}{l}\text { Translation of the mRNA } \\
\text { occurs in the cytosol of the } \\
\text { host cell preventing the } \\
\text { further risk of any kind of } \\
\text { integration into the host } \\
\text { genome. }{ }^{20}\end{array}$ & $\begin{array}{l}\text { - The main limitation is } \\
\text { the safety issues with the } \\
\text { reactogenicity that have } \\
\text { been reported for many } \\
\text { RNA based vaccines. } \\
\text { - Instability is another } \\
\text { limitation. }{ }^{20}\end{array}$ \\
\hline 2. & $\begin{array}{l}\text { Moderna } \\
\text { COVID-19 } \\
\text { vaccine } \\
\text { (mRNA- } \\
1273)\end{array}$ & $\begin{array}{l}\text { US (Canada, Israel, Saudi } \\
\text { Arabia, Switzerland, United } \\
\text { Kingdom, United States, EU, } \\
\text { Faroe Islands, Greenland, } \\
\text { Iceland, Norway) }\end{array}$ & $\begin{array}{l}\text { Translation of the mRNA } \\
\text { occurs in the cytosol of the } \\
\text { host cell preventing the } \\
\text { further risk of any kind of } \\
\text { integration into the host } \\
\text { genome. }\end{array}$ & $\begin{array}{l}\text { - The main limitation is } \\
\text { the safety issues with the } \\
\text { reactogenicity that have } \\
\text { been reported for many } \\
\text { RNA based vaccines. } \\
\text { - Instability }{ }^{20}\end{array}$ \\
\hline 3. & CoronaVac & $\begin{array}{l}\text { China (China, Bolivia, Turkey, } \\
\text { Indonesia, Brazil, Chile) }\end{array}$ & $\begin{array}{l}\text { Translation of the mRNA } \\
\text { occurs in the cytosol of the } \\
\text { host cell preventing the } \\
\text { further risk of any kind of } \\
\text { integration into the host } \\
\text { genome. } .^{20}\end{array}$ & $\begin{array}{l}\text { - The main limitation is } \\
\text { the safety issues with the } \\
\text { reactogenicity that have } \\
\text { been reported for many } \\
\text { RNA based vaccines. } \\
\text { - Instability }{ }^{20}\end{array}$ \\
\hline 4. & $\begin{array}{l}\text { COVID- } 19 \\
\text { Vaccine } \\
\text { AstraZeneca } \\
\text { (AZD1222) }\end{array}$ & $\begin{array}{l}\text { UK (UK, Argentina, El } \\
\text { Salvador, Dominican Republic, } \\
\text { India, Bangladesh, Mexico, } \\
\text { Nepal, Pakistan, Brazil, Saudi } \\
\text { Arabia, Iraq, Hungary, } \\
\text { Thailand) }\end{array}$ & $\begin{array}{l}\text { Translation of the mRNA } \\
\text { occurs in the cytosol of the } \\
\text { host cell preventing the } \\
\text { further risk of any kind of } \\
\text { integration into the host } \\
\text { genome. }\end{array}$ & $\begin{array}{l}\text { - The main limitation is } \\
\text { the safety issues with } \\
\text { the reactogenicity that } \\
\text { have been reported for } \\
\text { many RNA based } \\
\text { vaccines. } \\
\text { - Instability }{ }^{20}\end{array}$ \\
\hline 5. & Sputnik V & $\begin{array}{lr}\text { Russia (Russia, } & \text { Belarus, } \\
\text { Argentina, } & \text { Guinea } \\
\text { (experimental use), Bolivia, } & \text { Blgeria, Palestine, Venezuela, } \\
\text { Paraguay, Turkmenistan, } \\
\text { Hungary, UAE, Serbia, Iran) }\end{array}$ & $\begin{array}{l}\text { Translation of the mRNA } \\
\text { occurs in the cytosol of the } \\
\text { host cell preventing the } \\
\text { further risk of any kind of } \\
\text { integration into the host } \\
\text { genome. }{ }^{20}\end{array}$ & $\begin{array}{l}\text { - The main limitation is } \\
\text { the safety issues with } \\
\text { the reactogenicity that } \\
\text { have been reported for } \\
\text { many RNA based } \\
\text { vaccines. } \\
\text { - Instability }\end{array}$ \\
\hline 6. & BBIBP CorV & $\begin{array}{l}\text { Russia (China, Bahrain, United } \\
\text { Arab Emirates, Egypt, Jordan, } \\
\text { Iraq, Pakistan, Serbia, Peru) }\end{array}$ & $\begin{array}{l}\text { - It mainly shows } \\
\text { specifically high gene } \\
\text { delivery into the host } \\
\text { cell with a vigorous } \\
\text { immune response. } \\
\text { - It mainly avoids the } \\
\text { infectious particle and } \\
\text { it is used widely for } \\
\text { MERS-CoV with } \\
\text { positive results from } \\
\text { trials. }\end{array}$ & $\begin{array}{l}\text { - The main limitation of } \\
\text { this vaccine is that the } \\
\text { host possesses the } \\
\text { immunity against vector } \\
\text { due to prior exposure } \\
\text { and reducing the } \\
\text { efficacy. } \\
\text { - It may lead to the cause } \\
\text { of cancer due to the } \\
\text { integration of the viral } \\
\text { genome into the genome } \\
\text { of the host. }{ }^{19}\end{array}$ \\
\hline
\end{tabular}




\begin{tabular}{|c|c|c|c|c|}
\hline 7. & $\begin{array}{l}\text { EpiVacCoro } \\
\text { na }\end{array}$ & Russia & $\begin{array}{l}\text { Translation of the mRNA } \\
\text { occurs in the cytosol of the } \\
\text { host cell preventing the } \\
\text { further risk of any kind of } \\
\text { integration into the host } \\
\text { genome. } .^{20}\end{array}$ & $\begin{array}{l}\text { - The main limitation is } \\
\text { the safety issues with } \\
\text { the reactogenicity that } \\
\text { have been reported for } \\
\text { many RNA based } \\
\text { vaccines. } \\
\text { - Instability. }\end{array}$ \\
\hline 8. & Covaxin & India & $\begin{array}{l}\text { The main advantage of } \\
\text { Covaxin is it is safer and } \\
\text { stable as it compared to } \\
\text { LAVs. } \\
\text { Covaxin has the pre- } \\
\text { existing infrastructure and } \\
\text { technology as it is required } \\
\text { for the development } \\
\text { As it already been tested } \\
\text { for the SARS-CoV and the } \\
\text { various other diseases, it } \\
\text { can also be used along with } \\
\text { the adjuvants to increase } \\
\text { the immunogenicity. }\end{array}$ & $\begin{array}{l}\text { - The main limitation of } \\
\text { Covaxin Is it requires } \\
\text { the supporter shots to } \\
\text { maintain immunity. } \\
\text { - A large number of } \\
\text { viruses need to be } \\
\text { handled and the } \\
\text { integrity of the } \\
\text { immunogenic particles } \\
\text { of the virus must be } \\
\text { maintained. }\end{array}$ \\
\hline
\end{tabular}

\section{Side Effects of Corona Vaccine:}

A Corona vaccine can produce mild adverse effects right after taking the first/second dose, including:

1. Pain, Redness, or Swelling where the vaccine was given

2. Fever

3. Fatigue

4. Headache

5. Muscle Pain

6. Chills

\section{Joint pain}

It is mandatory to monitor the patient for the next 15 minutes after taking the Covid 19 Vaccine shot. Most of the side effects occur within the next 3 days after vaccination.

If someone has a history of allergic reactions which is not related to vaccines or injectable medications, they can still take Covid 19 Vaccine. If someone getting an immediate allergic reaction after getting the first dose of Covid 19 Vaccine, then he/she should not take the second dose of the vaccine.

There is no research currently available on the safety of Covid 19 vaccines in pregnant/breastfeeding women. If someone chooses to get the vaccine who is pregnant / breastfeeding women, then before taking the shot she should consult with her physician. ${ }^{21}$

In clinical trials, reactogenicity symptoms (side effects that happen within 7 days of getting vaccinated) were common but were mostly mild to moderate. Side effects (such as fever, chills, tiredness, and headache) throughout the body were more common after the second dose of the vaccine. Most side effects were mild to moderate. However, a small number of people had severe side effects that affected their ability to do daily activities ${ }^{22}$.

\section{How Covid 19 are vaccines being distributed in India?}

Due to the limited availability of the Covid 19 vaccine, everyone will not be able to get the vaccine.

The ACIP (Advisory Committee on Immunization Practices) has advised that in the $1^{\text {st }}$ phase of the trial Covid 19 vaccine should be given to healthcare workers and adult residents for longterm care.

The next precedence group includes people whose age is 75 or more than that and frontline essential workers. 
The next priority group includes people ages $65-$ 74 and $16-64$ that are at high risk of severe Covid 19 due to immune-compromised status. ${ }^{21}$

\section{Who should not get the Covid 19 vaccine in India?}

The Covid 19 vaccine which is available in the market is not meant for children under age 16 .

The Central government of India has prepared one list of people who should not be vaccinated (Covid 19).

1. People having a history of anaphylactic or allergic reactions should not take a Vaccine.

2. Pregnant women or who are not sure about their pregnancy and lactating mother should not take the vaccine.

3. Covid 19 patients who have been treated with anti-sars-Cov-2 monoclonal antibodies or coalescent plasma should not take the vaccine.

4. Those who are hospitalized due to any sickness should not take vaccine. ${ }^{23}$

\section{Different Kinds of Covid-19 Vaccines Available In India.}

\section{Sputnik vaccine:}

It is the world's first registered vaccine against Covid 19, Based on a well-studied human Adenoviral vector-based platform.

Efficacy for this vaccine was found to be $91.4 \%$, by Gamaleya Research Institute of Epidemiology and microbiology. Sputnik vaccine was registered in the market on 11 August 2020.

The result of Phase $1 \& 2$ studies of this vaccine was published on $4^{\text {th }}$ September 2020. The result of Phase 3 trials was published in December 2020 in which around 22714 participants have participated. The result of phase 3 trials claims that this vaccine has $91.4 \%$ efficacy.

After the respective trials, the possible adverse effects were reported like Muscle pain, Weakness, Headache. ${ }^{24}$

\section{Covaxin vaccine:}

This vaccine was developed by Bharath biotech. On Nov-16, 2020 Bharat biotech started its phase 3 trial. On December 1, 2020, this vaccine got approval for emergency use. The number of participants in the phase 3 clinical trial was around 26,000 . The result of phase 3 trials claims that $62 \%$ effective against Covid-19
After the respective trials, the possible adverse effects were reported like severe allergic reactions, headache, dizziness. ${ }^{25}$

\section{Covishield:}

This vaccine is India's first indigenous Covid-19 Vaccine. Covishield vaccine was manufactured by the University of Oxford, AstraZeneca. The result of various trials claims that it is having around $78.8 \%$ efficacy towards corona.

It is a 2-dose vaccination regimen, which is given 28 days apart.

A common side effect that was reported after trials are Headache, Nausea, Muscle pain.

There are some uncommon side effect which was reported during trials, those are Enlarged lymph nodes, Abdominal Pain, Excessive sweating. ${ }^{26}$

\section{Pfizer vaccine:}

The U.S. Food and Drug Administration on December 11, 2020, issued the $1^{\text {st }}$ emergency use authorization (EUA) for the prevention of Covid 19.

It is known as BNT162b2 in the market. This vaccine was manufactured by Pfizer, INC, and BioNTech. It is an mRNA type of vaccine. The results of trials show that this vaccine is having $52 \%$ efficacy after $1^{\text {st }}$ dose and $95 \%$ efficacy after $2^{\text {nd }}$ dose.

After the respective trials, the possible adverse effects were reported like Pain swelling, redness in the arm where the shot has been taken. ${ }^{27}$

\section{Comorbid Strategy}

This would be the "impetus stage" of the vaccine roll-out and would cover about 15 percent of the U.S. population in total. It would be divided into two parts:

Phase 1a groups include: High-risk workers in health care facilities and first responders.

Phase 1b groups includes: people of all ages groups with underlying and comorbid conditions putting them at considerably higher risk. It also includes elderly people living in congested and overcrowded localities.

Although experts couldn't make sure which underlying conditions put people at a considerably high risk of COVID-19 or death, the U.S. Centers for Disease Control experts still is gathering information regarding this topic, per the paper. The following are the list of factors associated with an 
increased risk of severe COVID-19: Cancer, Chronic kidney disease, Chronic obstructive pulmonary disease (COPD), Immune compromised state from solid organ transplant, Obesity (body mass index $[\mathrm{BMI}] \geq 30$ ), Serious heart conditions (e.g. heart failure, coronary artery disease, cardiomyopathies), Sickle cell diabetes, Type 2 diabetes.

However, it would be uncontrollable to vaccinate all patients with any of the listed conditions in Phase $1 \mathrm{~b}$, in the meantime millions of individuals in the United States would be involved. Therefore, the initial groups of recipients are needed to be restricted to those with two or more of that comorbid conditions. ${ }^{28}$

"It should be noted that as the relationship between severe COVID-19 disease and certain comorbid conditions becomes clearer, this list is subject to evolve," write the authors.

They go on to add that about 75 percent of adults hospitalized for COVID-19 in the United States from March 1 to August 15 had at least two comorbid conditions, and more than 60 percent had at least three underlying conditions, per Coronavirus Disease 2019 (COVID-19) Associated Hospitalization Surveillance Network (COVID-NET) data. ${ }^{28}$

Phase 2: This phase covers an approximately 30 to 35 percent of the American population. Estimated 45 to 50 percent of the population are covered in combined phase 1 and phase 2. It also includes critical risk workers (those who are both in industries vital for running the society are at considerably high risk of exposure), teachers and school staff, also people of all age groups with comorbid and underlying illnesses that put them at moderately high risk, people in group homes and homeless shelters with disabilities or in recovery, and people in, jails, detention centers, prisons or any other similar facilities, and staffs working in such facilities.

In this phase, peoples with any one of the above listed conditions in Phase $1 \mathrm{~b}$ would be able to get the vaccine. The authors noted that other comorbid and underlying conditions might be included for this phase as more research is being done. ${ }^{29}$

For instance, the CDC has a list of comorbid and underlying conditions that might place individuals at increased risk and that could possibly be considered for this phase: Asthma (moderate to severe), Cerebrovascular disease, Cystic fibrosis,
Hypertension, Immune compromised state from blood or bone marrow transplant, Immune deficiencies, HIV/AIDS, Use of corticosteroids or use of other immunosuppressive medicines, Neurologic conditions, Liver disease, Pregnancy, Pulmonary fibrosis, Smoking, Thalassemia and, Type 1 diabetes.

Approximately 12 percent of adults hospitalized for COVID-19 in the United States between March 1 and August 15 of this year had one select comorbid or underlying condition, per the COVIDNET data.

At this interval, the authors noted that they cannot precisely estimate the number of individuals in this group of population since they can't interpret for those with multiple co-morbid conditions in Phase $1 \mathrm{~b}$, but it would include tens millions of people. ${ }^{29}$

In the meantime, the older adult population included in this group for study is assessed to include over 49.2 million older adults, if "older adults" is reflected people age 65 and older. (However, the authors write that they submit to the Advisory Committee on Immunization Practices to assess the specific age guidelines as more health and vaccine data are available). ${ }^{29}$

"The case fatality proportion for COVID-19 is substantially higher among older adults in the United States, and the rate of hospitalization for COVID-19 increases with age," note the authors. Given the high risk of disease and death due to COVID-19 outbreak among older adults of peoples group, one could debate that age is an indispensible condition for COVID-19. ${ }^{28,29}$

\section{Conclusion:}

Global efforts in development of coronavirus vaccine is at a peek acceleration and hopefully the likelihood of the present vaccines and under developing vaccines will be safe and effective for all age group people. However, this vital landmark is only the first step in an equally vital challenge: to vaccinate the majority of global population. The sole to any success policy is to reestablish trust in the objectivity of vaccine and the honesty in approval procedure. ${ }^{30}$

Even though the vaccination strategy throughout the globe is in peak, the people are asked to follow the similar guidelines to prevent the transmission of corona virus. Therefore throughout the world, several ministries of health and family welfare have asked people to maintain social distancing, wearing facemasks in public, using hand sanitizers, 
washing hands, avoid crowded places and maintain personal hygiene. ${ }^{31,32}$

\section{Abbrevations:}

1. COVID-19 - Coronavirus Disease of 2019

2. NEGVAC - National Expert Group of Vaccine Administration for Covid -19

3. SARS CoV - Severe Acute Respiratory Syndrome Coronavirus

4. MERS- CoV - Middle East Respiratory Syndrome Coronavirus

5. DNA - Deoxyribonucleic Acid

6. RNA - Ribonucleic Acid

7. GSK - Glaxo Smith Kline

8. EMA - Exponential Moving Average

9. EU - European Union

10. IEC - International Electrotechnical Commission

11. ANMs - Auxiliary Nurse Midwife

12. ASHAs - Accredited Social Health Activist

13. AWW - Anganwadi Workers

14. SHGs - Self Help Groups

15. MAS - Mahila Arogya Samitis

16. PRIs - Panchayati Raj Institutions

17. NSS - National Service Scheme

18. NYKS - Nehru Yuva Kendra Sangathan

19. CSO - Chief Scientific Officer

20. CBOs - Community Based Organizations

21. ToT - Conducting National Training for Trainers

22. SBCC - Social And Behavior Change Communication

23. NEGVAC - National Expert Group on Vaccine Administration for COVID- 19

24. NIHR - National Institute for Health Research

25. ACIP - Advisory Committee on Immunization Practices

26. EUA - emergency use authorization

27. HIV - Human Immunodeficiency Virus

28. AIDS - Acquired Immune Deficiency Syndrome

\section{References:}

1. Duan K, Liu B, Li C, Zhang H, Yu T, Qu J, Zhou M, Chen L, Meng S, Hu Y, Peng C. Effectiveness of convalescent plasma therapy in severe COVID-19 patients. Proceedings of the National Academy of Sciences. 2020 Apr 28;117(17):9490-6.
2. Kaur SP, Gupta V. COVID-19 Vaccine: A comprehensive status report. Virus research. 2020 Aug 13:198114.

3. Wang D, Hu B, Hu C, Zhu F, Liu X, Zhang J, Wang B, Xiang H, Cheng Z, Xiong Y, Zhao Y. Clinical characteristics of 138 hospitalized patients with 2019 novel coronavirus-infected pneumonia in Wuhan, China. Jama. 2020 Mar 17;323(11):1061-9.

4. Satish Kumar BP, Paul P, Ghosh S, Ravindra BN, Roy AD. General awareness and safety measures to combat covid-19.

5. Zachariah P, Johnson CL, Halabi KC, Ahn D, Sen AI, Fischer A, Banker SL, Giordano M, Manice CS, Diamond R, Sewell TB. Epidemiology, clinical features, and disease severity in patients with coronavirus disease 2019 (COVID-19) in a children's hospital in New York City, New York. JAMA pediatrics. 2020 Oct 1;174(10):e202430-.

6. https://www.who.int/emergencies/diseases/ novel-coronavirus-2019/covid-19-vaccines

7. Lurie N, Saville M, Hatchett R, Halton J. Developing Covid-19 vaccines at pandemic speed. New England Journal of Medicine. 2020 May 21;382(21):1969-73.

8. Caddy S. Developing a vaccine for covid19.

9. Gao Q, Bao L, Mao H, Wang L, Xu K, Yang M, Li Y, Zhu L, Wang N, Lv Z, Gao H. Development of an inactivated vaccine candidate for SARS-CoV-2. Science. 2020 Jul 3;369(6499):77-81.

10. https://www.vaccineseurope.eu/

11. https://ec.europa.eu/commission/presscorn er/detail/en/ip_20_1103

12. https://www.mohfw.gov.in/pdf/Covid19Co mmunicationStrategy2020.pdf

13. https://www.cdc.gov/coronavirus/2019ncov/vaccines/vaccine-benefits.html

14. https://www.ndtv.com/india-news/whowill-get-covid-19-vaccine-first-how-toregister-all-you-need-to-know-2346827

15. https://scroll.in/article/983517/what-will-ittake-to-vaccinate-india-against-covid-19

16. Barnabas, R. V., \& Wald, A. A Public Health COVID-19 Vaccination Strategy to Maximize the Health Gains for Every Single Vaccine Dose. ( APA) Barnabas RV, Wald A. A Public Health COVID-19 Vaccination Strategy to Maximize the Health Gains for Every Single Vaccine Dose.(vancover) 
17. https://www.scientificamerican.com/article/wh o-will-get-a-covid-19-vaccine-first-accessplans-are-taking-shape/

18. https://thediplomat.com/2021/01/chinasambitious-covid-19-vaccine-targets/

19. https://www.raps.org/news-and-articles/newsarticles/2020/3/covid-19-vaccine-tracker

20. Kaur, S. P., \& Gupta, V. (2020). COVID-19 Vaccine: A comprehensive status report. Virus research, 198114. ( APA) Kaur SP, Gupta V. COVID-19 Vaccine: A comprehensive status report. Virus research. 2020 Aug 13:198114. (vancover)

21. https://www.mayoclinic.org/diseasesconditions/coronavirus/indepth/coronavirus-vaccine/art-20484859

22. Kaur SP, Gupta V. COVID-19 Vaccine: A comprehensive status report. Virus research. 2020 Aug 13:198114.

23. https://www.livemint.com/news/india/covi d19-vaccinations-drive-these-peopleshould-not-get-the-jab-full-list11610721646644.html

24. https://sputnikvaccine.com/aboutvaccine.html

25. https://www.bharatbiotech.com/covaxin.ht $\mathrm{ml}$

26. https://m.timesofindia.com/lifestyle/health-fitness/healthnews/coronavirus-vaccine-covishield-vs- covaxin-all-you-need-to-know-aboutindias-approved-homegrownvaccines/amp_etphotostory/80091866.cms

27. https://www.fda.gov/emergencypreparedness-and-respone/coronavirusdisease-2019-covid-19/pfizer-biontechcovid-19-vaccine

28. COVID 19 Vaccination by Our World in Data available at https://ourworldindata.org/covidvaccinations

29. Anon . 2020. COVID-19 Treatment and Vaccine Tracker.

30. Volpp KG, Loewenstein G, Buttenheim AM. Behaviorally informed strategies for a national COVID-19 vaccine promotion program. JAMA. 2021 Jan 12;325(2):1256.

31. Kurian BP, Daniel S, Ghosh S, Paul P, Reddy MA, Das L, Darshan JC, Roy AD. The Need of Understanding the Importance and Use of Face Masks. Journal of Current Medical Research and Opinion. 2021 Feb 2;4(02).

32. Jc, Darshan \& H V, Annegowda \& Zuber, Mohammed \& Ghosh, Sayantan \& Paul, Prolay. (2021). Hand Sanitizer: A Comprehensive Narrative Review. 66. 109114. 10.47583/ijpsrr.2021.v66i01.017.
How to cite this article: Das, D. L., A, D. M., Paul, D. P., \& Ghosh, D. S. (2021). Are We Ready For Covid - 19 Vaccines? - A General Side Effects Overview. Journal of Current Medical Research and Opinion, 4(02).

https://doi.org/10.15520/jcmro.v4i02.398 